\title{
O currence of co-infection by Leishmania (Leishmania) chagasi and Trypanosoma (Trypanozoon) evansi in a dog in the state of Mato Grosso do Sul, Brazil
}

\section{Elisa San Martin Mouriz Savani/ ${ }^{+}$, Vania Lúcia Brandão Nunes* , Eunice Aparecida Bianchi Galati**, Tiago Moreno Castilho***, Fernando Shiroma de Araujo*, Iêda Maria Novaes Ilha*, Maria Cecília Gibrail de O liveira Camargo, Sandra Regina Nicoletti D'Auria, Lucile Maria Floeter-Winter***}

\begin{abstract}
Laboratório de Zoonoses e Doenças Transmitidas por Vetores da Vigilância em Saúde, Prefeitura do Município de São Paulo, Rua Santa Eulália 86, 02031-020 São Paulo, SP, Brasil *Centro de Ciências Biológicas Agrárias e da Saúde, Universidade para o Desenvolvimento do Estado e da Região do Pantanal, Campo Grande, MS, Brasil **Faculdade de Saúde Pública ***Instituto de Biociências, Universidade de São Paulo, São Paulo, SP, Brasil
\end{abstract}

A natural case of co-infection by Leishmania and Trypanosoma is reported in a dog (Canis familiaris) in southwestern state of Mato Grosso do Sul, Brazil. Both amastigote and trypomastigote forms were observed after Giemsa staining of cytological preparations of the dog's bone marrow aspirate. No parasite was detected using medium culture inoculation of the sample. DNA obtained from the bone marrow aspirate sample and from the blood buffy coat was submitted to polymerase chain reaction $(P C R)$ with a set of $r D N A$-based primers S4/S12. The nucleotide sequence of the PCR product was identical to that of Trypanosoma (Trypanozoon) evansi. The S4/S12 PCR was then used as template in a nested-PCR using a specific Leishmania set S17/S18 as primers, to explain the amastigote forms. The nucleotide sequence of the new PCR product was identical to that of Leishmania (Leishmania) chagasi. This case, as far as we know, is the first report of a dog co-infected with these parasites, suggesting that besides L. (L.) chagasi, the natural transmission of T. (T.) evansi occurs in the area under study.

Key words: trypanosomatid identification - rDNA-based polymerase chain reaction - epidemiology - natural reservoirs - Brazil

In the state of Mato Grosso do Sul, as in other Brazilian states, both American cutaneous leishmaniasis (ACL) and American visceral leishmaniasis (AVL) are widespread (Nunes 2001, Galati et al. 2003).

The domestic dog (Canis familiaris) has been considered an important reservoir of the Leishmania (Leishmania) chagasi in periurban and urban environments (Barbosa-de-Deus et al. 2002); however, the role of this animal in the ACL transmission cycle has not yet been clarified (Reithinger \& Davies 1999).

Trypanosoma (Trypanozoon) evansi is the agent of a serious disease, known locally as "mal de cadeiras", which causes considerable mortality among horses of the Pantanal Matogrossense, resulting in significant economic loss. Little is known of this parasite as regards its survival and transmission (Davila et al. 2003), which occurs mechanically via haematophagous Diptera, mainly by Stomoxys sp. and Tabanus sp. (Queiroz et al. 2000).

Besides horses (Franke et al. 1994, Queiroz et al. 2000) and dogs (Stevens et al. 1989, Franke et al. 1994, Nunes

Financial support: Fundação Manoel de Barros/Uniderp, Fundect, grant 010/02, Fapesp, CNPq

${ }^{+}$Corresponding author. E-mail: elisasanmar@yahoo.com.br Received 22 August 2005

Accepted 5 September 2005
1996, Queiroz et al. 2000, Davila et al. 2003), infection by T. (T.) evansi has been found in bovines, buffaloes, sheep (Davila et al. 2003), capybaras (Hydrochaeris hydrochaeris) (Stevens et al. 1989, Franke et al. 1994), and coatis (Nasua nasua) (Nunes \& Oshiro 1990, Queiroz et al. 2000).

In the Guaicurus settlement, Bonito county, Mato Grosso do Sul, the presence of insect vectors of leishmaniasis, human cases of cutaneous leishmaniasis, and canine visceral leishmaniasis have been identified, although infection by other trypanosomatids has not so far been detected (Nunes 2001).

During February 2003, blood samples of 129 local dogs were collected to carry out a canine survey exclusively for leishmaniasis. The sera samples obtained were submitted to the indirect immunofluorescent antibody test (IFAT) and the enzyme-linked immunosorbent assay (ELISA). In June 2003, samples of both blood and bone marrow aspirate were taken from 24 reagent dogs. These samples were subsequently analyzed by the use of serological, parasitological, and polymerase chain reaction (PCR) techniques.

The first and second sera samples from a dog, called Xebinha, which presented clinical signs of visceral leishmaniasis, showed a positive reaction for ELISA. In the IFAT assay, using $L$. (L.) chagasi promastigotes as antigen, the first sample presented no reaction but the second sample proved to be positive at a 1:40 dilution. The 
same samples were positive at a 1:20 and 1:160 dilutions, respectively, using T. cruzi as antigen. Thus the immunological analysis indicated a cross reaction between Leishmania and Trypanosoma.

The microscopic analysis of a Giemsa stained smear of a bone marrow aspirate from this dog showed a few amastigote forms but was abundant in trypomastigotes. The morphological analysis of the smear identified the trypomastigotes as $T$. (T.) evansi (Fig. 1).

Samples of the bone marrow aspirate were either inoculated into blood agar base medium culture (Walton et al. 1977) with brain heart infusion and incubated at $23^{\circ} \mathrm{C}$, or inoculated into hamsters (Mesocricetus auratus). No parasites were detected by either procedure.

DNA was extracted from a bone marrow aspirate and from the buffy coat of Xebinha's blood in accordance with Castilho et al. (2003). About $20 \mathrm{ng}$ were used in a rDNA based PCR assay. Reactions were performed in a final volume of $50 \mu \mathrm{l}$ containing 1X PCR buffer, $2 \mathrm{mM}$ $\mathrm{MgCl}_{2}, 0.2 \mathrm{mM}$ dNTPs, $0.2 \mu \mathrm{M}$ of each primer and $2 \mathrm{U}$ Taq DNA polymerase. The first PCR was performed with primers S4 (5'- GAT CCA GCT GCA GGT TCA CC - 3') and S12 (5'- GGT TGATTC CGT CAA CGG AC - $3^{\prime}$ ) as described by Uliana et al. (1994). The DNA was denatured at $94^{\circ} \mathrm{C}$ for 3 min and then cycled 35 times at $94^{\circ} \mathrm{C}$ for $1 \mathrm{~min}$, at $50^{\circ} \mathrm{C}$ for $1 \mathrm{~min}$, and at $72^{\circ} \mathrm{C}$ for $1 \mathrm{~min}$. A final extension at $72^{\circ} \mathrm{C}$ was then performed for $7 \mathrm{~min}$. The amplified products were analyzed in a $2 \%$ agarose gel electrophoresis, stained with ethidium bromide. The nucleotide sequence of the resultant fragment of 520 bp was obtained directly by automatic sequencing using an ABI Big-Dye kit. The comparison of the nucleotide sequence of the sample matched only one of those described for T. (T.) evansi (Fig. 2).

To explain the presence of the amastigote, the $\mathrm{S} 4 / \mathrm{S} 12$ PCR product was used as template in nested-PCR with primers S17 and S18, specific for the Leishmania genus (Castilho et al., unpub. data). The reactions were performed under the same conditions as those described above. The S4/S12 PCR product $(1 \mu \mathrm{l})$ was denatured at $94^{\circ} \mathrm{C}$ for $4 \mathrm{~min}$ and cycled 30 times, each cycle was at $94^{\circ} \mathrm{C}$ for $1 \mathrm{~min}$, at $55^{\circ} \mathrm{C}$ for $1 \mathrm{~min}$ and at $72^{\circ} \mathrm{C}$ for $30 \mathrm{~s}$. The oligonucleotides S17 and S18 produced a 490 bp fragment, which was sequenced and identified as $L$. (L.) chagasi (Fig. 2).

It is interesting to note that $T$. (T.) evansi was observed in the bone marrow aspirate in greater number than was $L$. (L.) chagasi. This species was apparently more abundant in the blood, when the S17/S18 PCR products in both samples are compared. This observation contrasts with those recorded in the literature (Reithinger et al. 2000, 2003, Fisa et al. 2001). The possibility of using blood, which requires a less invasive procedure, should be considered in survey studies.

The discovery of a dog naturally co-infected with $L$. (L.) chagasi and T. (T.) evansi, as in this probable first report, indicates the presence of this latter trypanosomatid, already found in other areas in Mato Grosso do Sul (Nunes 1996, Stevens et al. 1989), also at the Guaicurus settlement. The occurrence of $L$. (L.) chagasi and T. (T.) evansi in the same animal and the cross-reactions which can occur in serology, makes it important to detect and/or isolate the parasite in epidemiological studies in dogs, horses and wild animals in this and other areas.

During 2005, in this same area, samples of blood were obtained from 130 dogs to investigate the infection by $T$. (T.) evansi in this animals. The examination of the smears under microscope revealed one more infected dog living close to the area where the first case (Xebinha) was found.
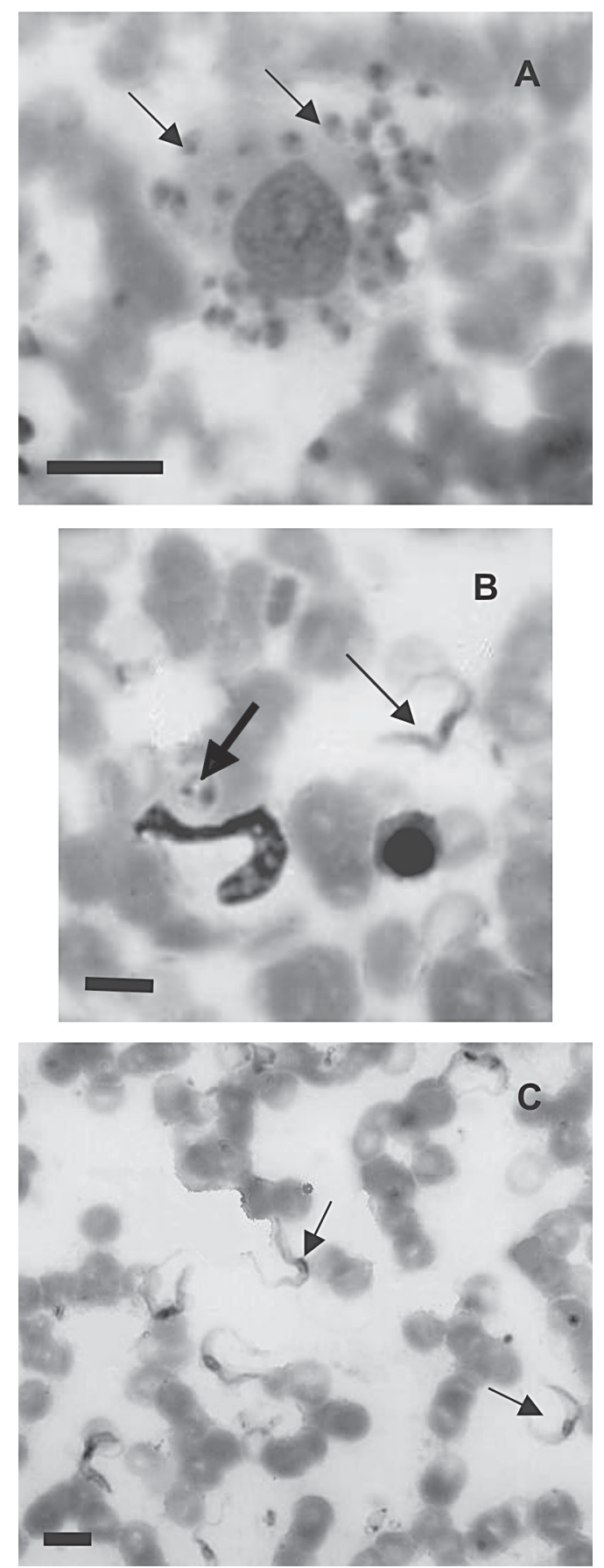

Fig. 1: microscopic view of smear of the bone marrow aspirate of the dog, Xebinha, stained by Giemsa. A: arrows point to amastigotes inside one macrophage; B: free amastigote (large arrow) and one trypomastigote (head arrow); C: abundance evaluation of trypomastigote forms of (the) Trypanosoma (Trypanozoon) evansi in the sample. Bars $=10 \mathrm{~mm}$. 


\begin{tabular}{|c|c|c|c|c|c|c|c|c|c|c|c|c|c|c|c|c|}
\hline \multirow[t]{3}{*}{ Organism } & \multicolumn{16}{|c|}{ rDNA sequence } \\
\hline & \multicolumn{16}{|c|}{ nucleotide position } \\
\hline & 1708 & & & & 1714 & & & & & & & 721 & & & & 1727 \\
\hline L. amazonensis & G A & A & $\mathbf{T}$ & $T$ G & C C & C C & $\mathbf{A}$ & $\mathbf{T}$ & $\sim \sim$ & A & G A & $\mathbf{A}$ & $\mathbf{T}$ & A G & C & A \\
\hline L. (Viannia) & $\cdot \cdot$ & . & . & .. & $\mathbf{T}$. & . & - & . & $\sim \sim$ & . & . $\mathrm{G}$ & . & . & . $\cdot$ & - & . \\
\hline L.chagasi & $\cdot$. & . & . & . . & .. & - . & . & . & $\sim \sim$ & . & . $\mathbf{G}$ & . & . & . . & . & . \\
\hline T.cruzi & $\cdot$. & . & . & . . & .. & . & . & $\cdot$ & $\sim \sim$ & . & . $\mathrm{G}$ & . & . & . . & . & . \\
\hline T.evansi & . $\mathrm{G}$ & . & . & . . & $\mathrm{T}$. & - . & . & C & $\mathrm{AC}$ & . & . $\mathrm{G}$ & . & $\mathrm{C}$ & . . & . & . \\
\hline Dog Xebinha 1 & . $\mathrm{G}$ & . & . & . . & $\mathbf{T}$. & - . & . & C & $\mathrm{AC}$ & . & . $\mathrm{G}$ & . & $\mathrm{C}$ & . . & . & . \\
\hline Dog Xebinha 2 & $\cdot \cdot$ & - & - & $\cdot \cdot$ & $\cdot \cdot$ & $\cdot$ & - & $\cdot$ & $\sim \sim$ & - & - $\mathrm{G}$ & . & - & $\cdot \cdot$ & $\cdot$ & - \\
\hline & 1945 & & & & & & & 954 & & & & & & 196 & & \\
\hline L.amazonensis & $\mathrm{CA}$ & C & A & $\mathbf{T A}$ & G A & A C & $\mathrm{C}$ & $\mathrm{C}$ & A & C T & $\mathrm{T}$ & G C & G G & $\mathrm{G} A$ & & \\
\hline L. (Viannia) & . $\cdot$ & • & • & . & .. & - . & $\cdot$ & . & $\cdot$ & . $\quad$. & • & . . & .. & .. & & \\
\hline L.chagasi & $\cdot \cdot$ & $\cdot$ & $\dot{0}$ & - & $\cdot \cdot$ & - $\cdot$ & $\mathbf{T}$ & - & $\cdot$ & - $\cdot$ & $\cdot$ & $\cdot$. & $\cdot \cdot$ & - $\cdot$ & & \\
\hline T.cruzi & $\cdot$. & $\cdot$ & G & - & .. & .. & $\cdot$ & . & · & . . & . & .. & . $\cdot$ & . $\cdot$ & & \\
\hline T.evansi & $\cdot \cdot$ & $\cdot$ & G & - & $\cdot \cdot$ & - $\cdot$ & $\cdot$ & . & $\cdot$ & . . & • & . & . & $\cdot$ & & \\
\hline Dog Xebinha 1 & $\cdot \cdot$ & - & G & • & . $\cdot$ & - $\quad$. & $\cdot$ & $\cdot$ & $\cdot$ & - $\cdot$ & $\cdot$ & $\cdot \cdot$ & $\cdot \cdot$ & $\cdot \cdot$ & & \\
\hline Dog Xebinha 2 & $\cdot \cdot$ & $\cdot$ & $\cdot$ & . $\cdot$ & . $\cdot$ & - . & $\mathbf{T}$ & . & . & . & . & . . & . . & $\cdot$. & & \\
\hline
\end{tabular}

Fig. 2: organism identification by SSU rDNA sequence comparison. Nucleotide sequences of reference strains and polymerase chain reaction (PCR) products of the DNA obtained from the dog sample with primers S4 and S12 (1) and nested-PCR with S17 and S18 (2) were aligned and compared. A dot represents base identity of the Leishmania (Leishmania) amazonensis sequence. The tildes indicate the position of a gap in the sequences of Leishmania species and Trypanosoma cruzi introduced to align the T. (T.) evansi sequence.

\section{REFERENCES}

Barbosa-de-Deus R, Mares-Guia ML, Nunes AZ, Costa KM, Junqueira RG, Mayrink W, Genaro O, Tavares CA 2002. Leishmania major-like antigen for specific and sensitive serodiagnosis of human and canine visceral leishmaniasis. Clin Diagn Lab Immunol 9: 1361-1366.

Castilho TM, Shaw JJ, Floeter-Winter LM 2003. New PCR assay using glucose-6-phosphate dehydrogenase for the identification of Leishmania species. J Clin Microbiol 41: 540-546.

Davila AM, Herrera HM, Schlebinger T, Souza SS, Traub-Cseko YM 2003. Using PCR for unraveling the cryptic epizootiology of livestock trypanosomosis in the Pantanal, Brazil. Vet Parasitol 117: 1-13.

Fisa R, Riera C, Gallego M, Manubens J, Portus M 2001. Nested PCR for diagnosis of canine leishmaniasis in peripheral blood, lymph node and bone marrow aspirates. Vet Parasitol 99: 105-111.

Franke CR, Greiner M, Mehlitz D 1994. Investigations on naturally occurring Trypanosoma evansi infections in horses, cattle, dogs and capybaras (Hydrochaeris hydrochaeris) in Pantanal de Pocone (Mato Grosso, Brazil). Acta Trop 58: 159-169.

Galati EAB, Nunes VLB, Cristaldo G, Da Rocha HC 2003. Aspectos do comportamento da fauna flebotomínea (Diptera: Psychodidae) em foco de leishmaniose visceral e tegumentar na Serra da Bodoquena e área adjacente, Estado de Mato Grosso do Sul, Brasil. Rev Patol Trop 32: 235261.

Nunes VLB 1996. Protozoários tripanosomatídeos encontrados em animais domésticos e silvestres em área do Planalto e do Pantanal Sul-mato-grossense. Mem Inst Oswaldo Cruz. 91(Suppl.): 27.
Nunes VLB 2001. Condicionantes para a Transmissão de Leishmanioses em Assentamento Agrícola do Incra e Adjacências, Planalto da Bodoquena, Estado do Mato Grosso do Sul, Brasil, 1998-1999, Thesis, Universidade de São Paulo, São Paulo, 164 pp.

Nunes VLB, Oshiro ET 1990. Trypanosoma (Trypanozoon) evansi in the coati from the Pantanal region of Mato Grosso do Sul state, Brazil. Trans R Soc Trop Med Hyg 84: 692.

Queiroz AO, Nehme-Russell NS, Brandão A, Jansen AM 2000. Homogeneity of Trypanosoma evansi isolates from domestic and sylvatic mammals from the Pantanal of Mato Grosso. Microbios 103: 27-30.

Reithinger R, Davies CR 1999. Is the domestic dog (Canis familiaris) a reservoir host of American cutaneous leishmaniasis? A critical review of the current evidence. Am J Trop Med Hyg 61: 530-541.

Reithinger R, Espinoza CJ, Courtenay O, Davies CR 2003. Evaluation of PCR as a diagnostic mass-screening tool to detect Leishmania (Viannia) spp in domestic dogs (Canis familiaris). J Clin Microbiol 41: 1486-1493.

Reithinger R, Lambson BE, Barker DC, Davies CR 2000. Use of PCR to detect Leishmania (Viannia) spp. in dog blood and bone marrow. J Clin Microbiol 38: 748-751.

Stevens JR, Nunes VLB, Lanham SM, Oshiro ET 1989. Isoenzyme characterization of Trypanosoma evansi isolated from capybaras and dogs in Brazil. Acta Trop 46: 213-222.

Uliana SRB, Nelson K, Beverley SM, Camargo EP, FloeterWinter LM 1994. Discrimination amongst Leishmania by polymerase chain reaction and hybridization with small subunit ribosomal DNA derived oligonucleotides. J Euk Microbiol 41: 324-330.

Walton BC, Shaw JJ, Lainson R 1977. Observations on the in vitro cultivation of Leishmania braziliensis. J Parasitol 63: 1118-1119. 